\title{
SOUTHEAST ASIA REGIONAL COOPERATION ON TACKLING MARINE PLASTIC LITTER
}

\author{
Febryani Sabatira
}

Lampung Sweeping Community, Indonesia, Email: febbysabatira14@gmail.com

Submitted: April 29, 2020; Reviewed: May 14, 2020; Accepted: June 2, 2020

\begin{tabular}{ll}
\hline \multicolumn{1}{c}{ Article Info } & \multicolumn{1}{c}{ Abstract } \\
\hline Keywords: & The sea covers $70 \%$ of the earth and is the source of \\
Marine, Plastic, Litters, & livelihood for people all over the world. It is estimated \\
Cooperations, ASEAN. & that each year 6-12 million tons of plastic are dumped into \\
& the ocean. In the Southeast Asian region, the concentration \\
DOI: & of marine plastic litter in the ocean has reached a severe \\
10.25041/lajil.v2i2.2033 & level. Six out of the 10 ASEAN countries are listed on the \\
& Top 20 of countries ranked by mass of the mismanaged \\
& plastic waste. Various legal instruments and supporting \\
& programs have been developed. However, the existence of \\
& these instruments and programs have not had a significant \\
& impact on combating marine plastic litter. This study aims \\
& to find out how a regional community can conquer the \\
& severe pollution of our oceans. This research uses \\
& normative legal analysis with secondary data sources and \\
& literature study techniques. The result of the research \\
& showed ASEAN initiated the regional cooperation \\
& amongst southeast Asia states in combating marine plastic \\
litters as the competent regional organisation that carried & out through institutional frameworks and subsidiary \\
working groups, which have enacted two regional soft-law & instruments, namely the Bangkok Declaration on Marine \\
Debris and the ASEAN Framework for Action on Marine & Debris.
\end{tabular}

\section{A. Introduction}

The ocean is a traditional source of food and livelihood for lots of people all over the world. Unfortunately, 6 to 12 million metric tonnes of plastic waste is estimated to enters the ocean per year and causing the marine environment to be polluted massively by the existence of plastic waste. ${ }^{1}$ Plastic waste has been a problem in the marine environment since the 1970s; however, only recently has it been identified as a global problem. ${ }^{2}$ Plastic waste is one type of pollutants

${ }^{1}$ M. Haward, "PLASTIC POLLUTION OF THE WORLD'S SEASAND OCEAN AS CONTEMPORARY CHALLENGE IN GOVERNANCE”, Nature Communications 9, no. 1 (2018): 1-3, 1, DOI: 10.1038/s41467-01803104-3.

${ }^{2}$ D. Xhantos, T. R. Walker, "INTERNATIONAL POLICIES TO REDUCE PLASTIC MARINE POLLUTION FROM SINGLE-USE PLASTIC", Elsavier Journal 118, no. 1-2 (2019): 17-26, 17, DOI: 10.1016/j.marpolbul.2017.02.048. 
that harms the environment due to the durability of the plastic that persisted for years without being degraded or decomposed in the marine ecosystem. ${ }^{3}$ One type of plastic made from polyethene $^{4}$ (PET) ) can have undesirable impacts on human and animal health due to the discharges of carcinogenic ${ }^{5}$ compounds that increase the risk of cancer, as well as the decomposition resulting in microplastics ${ }^{6}$ crawling up the food chain. ${ }^{7}$ A 2018 report by the Department of Marine and Coastal Resources, noted that at least 300 marine animals die on average from consuming fishing gear and plastic-based waste each year, and about $60 \%$ of these are whales and dolphins. ${ }^{8}$ As much as $54 \%$ of the 120 species of marine mammals listed as endangered species (Red List) by the International Union for Conservation of Nature (IUCN) and known to have been entangled by plastic waste. ${ }^{9}$ The data above has described the danger of plastic waste pollution to the marine biota ecosystem and the quality of the marine environment.

The problem of marine plastic litter has become a global concern, as well as in the Southeast Asian region. ${ }^{10}$ In 2015 research shows that 6 out of 11 Southeast Asian countries listed in the top 20 Countries Ranked by Mass of Mismanaged Plastic Waste. These countries are Indonesia (second), Philippines (third), Vietnam (fourth), Thailand (sixth), Malaysia (eighth), Myanmar (seventeenth), with total pollution reaching 1.4-3.54 million metric tonnes (MMT) per year. Plastic waste originating from the six countries exceeds the amount of plastic waste produced by China in the first place with total plastic waste pollution reaching 1.32-1.53 MMT per year. ${ }^{11}$

There have been several concrete cases related to the problem of marine plastic waste in the Southeast Asian regional seas. ${ }^{12}$ One of an example taken from the finding of a mass of plastic waste disseminated over nearly 10 kilometres was seen floating off the coast of the Gulf of Thailand province of Chumpon. It shows the complexity of marine plastic litter issue in the world's ocean, including Thailand, which ranks the sixth-worst sea pollutants in this world. ${ }^{13}$ According to the Pollution Control Department, Thailand annually produces around 2 million tons of plastic waste, and only $25 \%$ is recycled, the rest moves to incineration, and approximately 50,000 to 60,000 tons flows to the sea. Another example spotted at Tongkaina Beach in Manado, Indonesia, through a study conducted in 2019 which showed that the most common types of marine pollution found $58.2 \%$ of $1433.38 \mathrm{gr} / \mathrm{m} 2$ total weight marine pollution contains plastic litters. ${ }^{14}$ These cases prompted the regional organisation of the Association of

\footnotetext{
${ }^{3}$ Peter J. Kershaw, Marine Plastic Debris \& Microplastic (Nairobi:UNEP, 2016), 2.

${ }^{4}$ Polyethylene is a plastic material that is widely used by consumer products as plastic bags.

${ }^{5}$ Carcinogen is any substance, radionuclide, or radiation that promotes carcinogenesis, the formation of cancer. This may be due to the ability to damage the genome or to the disruption of cellular metabolic processes.

${ }^{6}$ Microplastics are small plastic pieces less than five millimeters long which can be harmful to our ocean and aquatic life

${ }^{7}$ Peter. J. Kershaw, Op. Cit., 3.

8 Luisa Gargani, "IMPACT OF MARINE LITTER", Frontiers in Marine Science 6, (2019): 1-8, 4, DOI: 10.3389/fmars.2019.0020

${ }^{9}$ Special Survival Commission, IUCN Red Categories and Criteria (Swiss: IUCN, 2012).

10 U. Rashid Sumaila, "COMPARATIVE VALUATION OF fiSHERIES IN ASIAN LARGE MARINE ECOSYSTEMS WITH EMPHASIS ON THE EAST CHINA SEA AND SOUTH CHINA SEA LMES”, DeepSea Research Part II 163, (2019): 96-101, 96, DOI: 10.1016/j.dsr2.2018.12.008.

${ }^{11}$ J. R. Jambeck, R. Geyer, \& C. Wiloex, "PLASTIC WASTE INPUTS FROM LAND TO OCEAN", Sciencemag 347, no. 6223 (2015): 768-771, 769, DOI: 10.1126/science.1260879.

${ }^{12}$ Aurélie V. Duhec, et al, "COMPOSITION AND POTENTIAL ORIGIN OF MARINE DEBRIS STRANDED IN THE WESTERN INDIAN OCEAN ON REMOTE ALPHONSE ISLAND, SEYCHELLES”, Marine Pollution Bulletin 96, no. 1-2 (2015): 76-86, 76, DOI: 10.1016/j.marpolbul.2015.05.042.

13 Piyaporn Wongruang, "SPECIAL REPORT: ALARM RAISED AS THAILAND DROWNS IN PLASTIC TRASH", The Nation Thailand, 05 may 2018.

${ }^{14}$ Markus T. Lasut, et al, "FROM CORAL TRIANGLE TO TRASH TRIANGLE- HOW THE HOT SPOT OF GLOBAL MARINE BIODIVERSITY IS THREATENED BY PLASTIC WASTE”, Proceedings of the
} 
Southeast Asian Nations (ASEAN) to take comprehensive steps to conquer marine plastic litter issue in its ocean. ${ }^{15}$

As stated in the Bangkok Declaration, the aim of establishing ASEAN was to establish cooperation between countries in Southeast Asia. ${ }^{16}$ Regional cooperation between Southeast Asia member states is the implementation of the mandate described on Principles 7 and 24 of the 1972 Stockholm Declaration as the main instruments of international environmental law, Article 194 paragraph (1) and Article 196 of UNCLOS 1982 as the main instruments of international law of the sea and UNEA-4/6 Resolution on Marine Plastic Litters and Microplastic as a global recommendation on marine environmental protection. ${ }^{17}$

The regional cooperation efforts of ASEAN member states are carried out through an institutional framework based on the ASEAN Blueprint 2025 as a commitment of ASEAN countries to improve the quality of life of the ASEAN people, especially in the aspect of improving the quality of the environment, includes prevention of marine waste, especially plastic pollution. ${ }^{18}$ Regional cooperation in Southeast Asia will be further illustrated through the following chart:

International Conference on Microplastic Pollution in the Mediterranean Sea, Springer Water, (2018): 108, DOI: 10.1007/978-3-319-71279-6_1.

${ }^{15}$ G. Beatriz, M. F. Mandy, L. Jolene, “MARINE PLASTIC POLLUTION IN ASIA:ALL HANDS ON DECK!", Chinese Journal of Environmental Law 3, no. 1 (2019): 19-46, 44, DOI: 10.1163/24686042-12340034.

${ }^{16}$ Abdul Muthalib Tahar and S Endang Prasetyawati, "KAJIAN HARMONISASI HUKUM PERSAINGAN TIGA NEGARA ANGGOTA ASEAN BERDASARKAN THE ASEAN REGIONAL GUIDELINES ON COMPETITION POLICY STUDY OF HARMONIZATION OF COMPETITION LAWS OF THREE ASEAN MEMBER COUNTRIES BASED ON THE ASEAN REGIONAL GUIDELINES ON COMPETITION POLICY," Cepalo 2, no. 1 (2019): 1-20, 2, DOI: 10.25041/cepalo.v2no1.1758.

17 Nguyen van Truong, Chu beiPing, "PLASTIC MARINE DEBRIS: SOURCES, IMPACTS AND MANAGEMENT", International Journal of Environmental Studies (2019): 10-20, 10, DOI: 10.1080/00207233.2019.1662211

18 https://asean.org/storage/2019/03/3.-Joint-Media-Statement-SAMM-5-March-2019-Thai-Logo.pdf., Accessed on March 5, 2019. 


\section{Chart 1.1}

Southeast Asia Regional Cooperation on Tackling Marine Plastic Litter

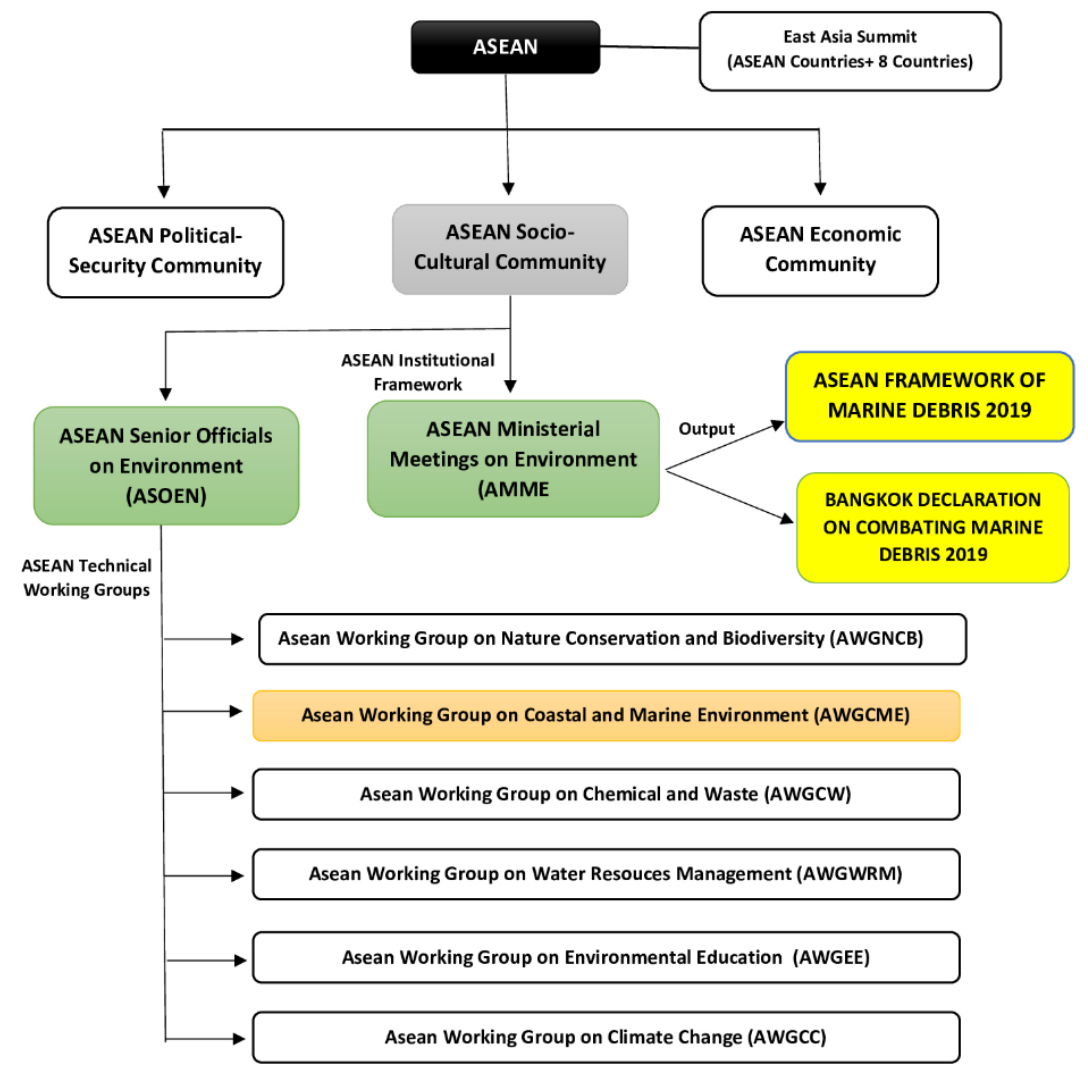

Sources: Lyons, Youna, Su, Theresa and Mei Lin Neo. A review of research on marine plastics in Southeast Asia: Who does what?. Singapore: National University of Singapore, 2019, 41.

ASEAN Working Groups on Coastal and Marine Environment (AWGCME) is the ASEAN technical working groups that straightly related to marine environment protection issues, including plastic litters pollution. ${ }^{19}$ Moreover, ASEAN has organised related activity centres, namely the ASEAN Conference on Reducing Marine Debris in the ASEAN Region in Thailand by the Ministry of Environment and Natural Resources. The conference was the result of the 20th ASEAN Working Group Meeting on the Coastal, and Marine Environment. It aims to bring together relevant ASEAN sectoral bodies and various stakeholders, including the government; international organisations, business and industry; academics and experts; civil society and youth, involved in various issues such as health and food safety; science, technology, and innovation and fisheries, including legal and regulatory frameworks to discuss ASEAN's further strategy in combating marine plastic litter more effectively, under the ASEAN Vision 2025 on governing biodiversity and natural resources for sustainable development. ${ }^{20}$

The establishment of various working groups and the execution of regional conferences on the tackling of marine plastic litters problems shows that ASEAN has given immense concern addressing the issue. It can be said that it is only about time ASEAN will eventually be able to

\footnotetext{
${ }^{19}$ Julius Cesar T, "MARINE ENVIRONMENTAL PROTECTION AND COOPERATION: AN ASEAN-CHINA FRAMEWORK?", RSIS Commentary, no. 113 (2017): 1-4, 3.

${ }^{20}$ ASEAN, Bangkok Declaration on Combating Marine Debris in ASEAN Region, (Jakarta: ASEAN Sekretariat, 2019), 3.
} 
conquer marine plastic litter in its region once the mandates implemented adequately. ${ }^{21}$ However, ASEAN does not yet have a binding regional action plan for its member states, which provoked the ineffectiveness of the implementation of the programmes. ${ }^{22}$ Moreover, it is indeed a concern that the implementation process will be a challenge for ASEAN countries, due to the principle of non-interference governing that all policies are under the government of each member states. ${ }^{23}$ Therefore, this study aims to examine regional cooperation between Southeast Asia countries conquers the severe pollution of our oceans caused by marine plastic litters. The method used in this study is normative legal research with the statutory approach by reviewing the material content and the philosophical foundation of the law. ${ }^{24}$ The data in this study used secondary data sources and literature study techniques.

\section{B. Discussion}

Discussion and analysis will further explain and describe 2 (two) main issues, which are the development of Southeast Asia regional cooperation in tackling marine plastic litters, and ASEAN Cooperative mechanism in addressing the marine plastic litters problem through the ASEAN institutional frameworks.

\section{The Development Of Southeast Asia Regional Cooperation In Tackling Marine Plastic Litters}

Plastics production increased rapidly from the 1950s, with global production reaching approximately 311 million tonnes in $2014 .{ }^{25}$ If the current trend of a $5 \%$ production increase per year remains, an additional 33 billion tons of plastic will have accumulated up around the globe by $2050 .^{26}$ Today, plastics have replaced the application of traditional materials in various sectors, including construction, transportation, household goods and packaging. ${ }^{27}$ Due to insufficient producer responsibility, lack of awareness over the consequences of littering, the short life cycle of many products and high consumption rates, the durability of plastic, inadequate sewage and waste management including poorly operated and illegal landfills are a series of factors prompting massive marine plastic pollution. ${ }^{28}$

However, existing various international legal instruments related to environmental protection do not yet contain specific stipulations related to tackling plastic litters issue. ${ }^{29}$ The matter of marine plastic litters began to be arranged into various legislative agendas after the

\footnotetext{
${ }^{21}$ Craig Forest, "STATE COOPERATION IN COMBATING TRANSBOUNDARY MARINE POLLUTION IN SOUTH EAST ASIA", Australian and New Zealand Maritime Law 30, no. 1 (2016): 78-89.

${ }^{22}$ Sarva M. P., Siti N. M., Shinichi A, "EXPLORATION OF MICROPLASTICS FROM PERSONAL CARE AND COSMETIC PRODUCTS AND ITS ESTIMATED EMISSIONS TO MARINE ENVIRONMENT: AN EVIDENCE FROM MALAYSIA", Marine Pollution Bulletin 136, (2018): 135-140, 136, DOI: 10.1016/j.marpolbul.2018.09.012.

${ }^{23}$ K. L. Koh, A. R. Nicholas, L. Lye, ASEAN Environmental Legal Integration (Cambridge: Cambridge University Press, 2016), 29.

${ }^{24}$ Tedy Nopriandi, Risky Fany Ardhiansyah,“ PARADIGM OF DEATH PENALTY (COMPARATIVE STUDY IN INDONESIA, SAUDI ARABIA AND CHINA)”, Lampung Journal of International Law (LaJIL) 2, no. 1 (2020): 47-56, 48.

${ }^{25}$. L. Ansje, "SOLUTION FOR GLOBAL MARINE LITTER POLLUTION”, Current Opinion in Environmental Sustainability, no. 28 (2017): 90-100, 91, DOI: 10.1016/j.cosust.2017.08.009.

${ }^{26}$ Stefanie Werner, "MARINE PLASTIC LITTER- A MASSIVE WASTE PROBLEM", Journal for Waste Resources and Residues 1, no. 1 (2018): 128-133, 128, DOI: 10.26403/detritus/2018.21.

${ }^{27}$ Lebreton L. C, et al, "RIVER PLASTIC EMISSIONS TO THE WORLD'S OCEANS", Nat. Commun 8, no.15611 (2017): 1-8, 2, DOI: 10.1038/ncomms15611.

28 Peter Dauvergne, "WHY IS THE GLOBAL GOVERNANCE OF PLASTIC FAILING THE OCEANS?", Global Environmental Changes 51, (2018): 22-31, 23, DOI: /10.1016/j.gloenvcha.2018.05.002

${ }^{29}$ Ma. Gregoria Joane P.T, et al, "MANAGEMENT FRAMEWORKS FOR COASTAL AND MARINE POLLUTION IN THE EUROPEAN AND SOUTHEAST ASIA REGION", Ocean and Management 135, (2017): 65-78, 67. DOI: 10.1016/j.ocecoaman.2016.11.003 0964-5691/
} 
adoption of UNEA 1/6 Resolution on Marine plastic litters and microplastic in 2014 by the United Nations Environment Program (UNEP), as the UN body in the scope of the environment. ${ }^{30}$ To date, UNEP, through its legislative authority, the United Nations Environment Assembly (UNEA) has issued a total of four Resolutions. The latest resolution, namely, UNEA-4 / Res. 4/6 on Marine Debris and Microplastics in 2019, explicitly stipulates regional cooperation recommendations mentioned in Paragraph 3 UNEA-4 which stated that all member states should "... strengthen coordination and cooperation by establishing, subject to the availability of resources and building on existing initiatives, a multi-stakeholder platform within the United Nations Environment Program to take immediate action towards the longterm elimination, through a life-cycle approach, of discharges of litter and microplastics into the oceans at the national, regional and international levels...". This paragraph then becomes a directive for countries to develop cooperation between states in combating marine plastic issues.

The series of resolutions adopted by the UNEA became the basis for the implementation of many marine environmental preservation programs by the state, international organisations, non-governmental organisations and other parties as an effort to implement the mandate to increase cooperation and partnerships at the regional level on the protection of the marine environment from plastic waste pollution. ${ }^{31}$ UNEP has established a series of programmes in tackling marine plastic litters, which will be explained below:

\section{Southeast Asia Regional Initiatives Under United Nations Environment Programmes (UNEP)}

In general, UNEP has two primary programs of global and regional cooperation in tackling marine plastic litters, namely the Global Program of Action for the Protection of the Marine Environment from Land-based Activities (GPA) and Regional Seas Programs (RSP) as the most extensive regional program in the world. The RSP was established and authorised in 1974 by UNEP. The RSP aims to address the problem of marine degradation by involving adjacent countries in collaboration to support the realisation of international environmental and development targets. ${ }^{32}$ To date, the RSP has comprised 18 marine regions from 146 countries that have joined 18 Regional Seas Conventions and Action Plans (RSCAP) or the Regional Sea Convention and Action Plan and particular protocols addressing the matter of the marine environment preservation, which explained in the following table.

\footnotetext{
${ }^{30}$ C. Giulia, and K. Konstantin, "ADVANCING THE INTERNATIONAL REGULATION OF PLASTIC POLLUTION BEYOND THE UNITED NATIONS ENVIRONMENT ASSEMBLY RESOLUTIONS ON MARINE LITTER AND MICROPLASTICS", Review of European,Comparative and International Environmental Law 27, no. 3 (2018): 234-244, 235, DOI: 10.1111/reel/12258.

${ }^{31}$ Joanna Vince, Britta Denise H, "PLASTIC POLLUTION CHALLENGES IN MARINE AND COASTAL ENVIRONMENTS: FROM LOCAL TO GLOBAL GOVERNANCE”, The Journal of the Society for Ecological Restoration 25, no. 1 (2016): 123-128, 124, DOI: 10.1111/rec.12388

${ }^{32}$ Porter Hoagland, D. Jin, UNEP Regional Seas Report and Studies No. 181 (Netherland: UNEP, 2006), 10.
} 
Table 1.1

Sea Area Division Administered By The RSP

\begin{tabular}{|c|c|c|}
\hline $\begin{array}{l}\text { UN Environment- } \\
\text { administered Regional } \\
\text { Seas Programmes }\end{array}$ & $\begin{array}{l}\text { Non-UN EnvTronment } \\
\text { administered Regional } \\
\text { Seas Programmes } \\
\text { established under the } \\
\text { auspices of UN } \\
\text { Environment }\end{array}$ & $\begin{array}{l}\text { Non-UN Environment } \\
\text { administered, } \\
\text { independently established } \\
\text { Regional Seas } \\
\text { Programmes }\end{array}$ \\
\hline $\begin{array}{l}\text { Caspian Sea } \\
\text { East Asian Seas } \\
\text { Eastern Africa } \\
\text { Region } \\
\text { Mediterranean } \\
\text { Region } \\
\text { North-West Pacific } \\
\text { Region } \\
\text { Western Africa } \\
\text { Region } \\
\text { Wider Caribbean } \\
\text { Region }\end{array}$ & $\begin{array}{ll}\text { - } & \text { Black Sea Region } \\
\text { North-East Pacific } \\
\text { Region } \\
\text { - } & \text { Pacific Region } \\
\text { Red Sea and Gulf of } \\
\text { Aden } \\
\text { - } \quad \text { ROPME Sea Area } \\
\text { - } \quad \text { South Asian Seas } \\
\text { South-East Pacific } \\
\text { Region }\end{array}$ & $\begin{array}{ll}- & \text { Arctic Region } \\
\text { - } & \text { Antarctic Region } \\
\text { Baltic Sea } \\
\text { North-East Atlantic } \\
\text { Region }\end{array}$ \\
\hline
\end{tabular}

Based on the table, it showed that the Southeast Asian ocean region had not been included in the list of sea area division administered by the RSP. Moreover, the Southeast Asian region does not yet have a specific regional action plan. Although, several countries in the Southeast Asia region are participating countries in The East Asian Sea Action Plan which was established in 1981 as a form of regional cooperation between East and Southeast Asian countries regarding the development and protection of the marine environment. ${ }^{33}$ To date, the countries involved in the mentioned action plan are Indonesia, Cambodia, Malaysia, the Philippines, Thailand, Singapore and Vietnam as representatives from Southeast Asia and China and Korea as representatives from East Asia. ${ }^{34}$ The establishment of the East Asia Seas Action plan is the starting point for the development of cooperation between countries in Southeast Asia in addressing the degradation of the marine environment, including pollution by plastic waste.

\section{ASEAN Cooperative Mechanism in Addressing the Marine Plastic Litters Problem Through the ASEAN Institutional Frameworks}

The United Nations Convention on the Law of the Sea (UNCLOS) Chapter XII (Articles 192-237) stipulates the protection and preservation of the marine environment. Countries are required to cooperate and take all necessary steps to prevent, reduce and control pollution of the marine environment from all sources. ${ }^{35}$ Moreover, Article 197 explicitly stated that "states shall cooperate on a global basis and regional basis, directly or through competent international organisations, in formulating and elaborating international rules, standards and recommended programs for the protection and preservation of the marine environment, taking into account characteristic regional features". Thus, this article becomes the legal basis for cooperation establishment on the protection of the marine environment at the regional level.

Realising the potential degradation regarding marine environment especially plastic pollution, Southeast member states are searching for effective strategies to tackle the issues. ${ }^{36}$ In that matter, marine plastic litter issues in the ASEAN regional sea began to be the main topic

\footnotetext{
33 Hugh Kikman, "THE EAST ASIAN SEAS UNEP REGIONAL SEAS PROGRAMME”, International Environment Agreements Springer 6, no. 3 (2006): 305-316, 306, DOI: 10.1007/S|074-006-9011-5.

${ }^{34} \mathrm{https}$ ://www.unenvironment.org/cobsea/who-we-are, Accessed on March 4, 2020.

${ }^{35}$ Article 194 (1) United Nations Conference on the Law of the Sea (UNCLOS) 1982.

${ }^{36}$ Khairunnisa Ahmad K, et al, "AN ASSESSMENT OF MARINE PROTECTED AREAS AS A MARINE MANAGEMENT STRATEGY IN SOUTHEAST ASIA: A LITERATURE REVIEW”, Ocean and Management 145, no. 1 (2017): 72-81, 73, DOI: 10.1016/j.ocecoaman.2017.05.008.
} 
of the regional forum since the East Asia Summit (EAS) Conference on Marine Debris on 6-7 September 2017 in Bali. ${ }^{37}$ The conference discussed strategies and solution findings on the marine plastic problem of the participating countries territorial waters by addressing the challenges in managing plastic waste and designing innovative solutions, as well as strengthening cooperation between parties from the local, national and regional levels. Subsequently, further conferences were held, namely the ASEAN Conference on Marine Debris. The ASEAN Conference on Marine Debris was organised by the Department of Marine and Coastal Resources and the Ministry of Natural Resources and Environment (MONRE) Thailand in coordination with the ASEAN Secretariat and the International Union for Conservation of Nature (IUCN) on 22-23 November 2017 in Phuket, Thailand. ${ }^{38}$ The result of the conference then became a recommendation for the ASEAN Member States to began to draft the ASEAN regional strategic plan on marine plastic litters problem through the ASEAN institutional framework (see Chart 1.1), which will be explained below.

\section{a. ASEAN Community}

At the 27th ASEAN summit in 2015, the leaders of the 10 ASEAN countries collectively signed The 2015 Kuala Lumpur Declaration on the Establishment of the ASEAN Community, marking a new historical stage in the development of ASEAN regional integration. ASEAN Community contains three pillars, namely the ASEAN Political-Security Community (APSC), the ASEAN Economic Community (AEC) and the ASEAN Socio-Cultural Community (ASCC). The meeting also adopted a set of concept documents, including Vision of the ASEAN Community in 2025, ASEAN Political-Security Community Blueprint in 2025, ASEAN Economic Community Blueprint in 2025, ASEAN Social and Cultural Community Blueprint in 2025. ${ }^{39}$ ASEAN Community is a multilateral agreement between ASEAN member states that aims to strengthen cooperation in the political, economic, socio-cultural, security sectors and improve environmental quality. ${ }^{40}$ ASCC is one of the three pillars of the ASEAN Community that related to environmental protection and preservation. The implementation of the objectives is written under the ASCC Blueprint 2025 as a commitment of ASEAN Member States which was substantially carried out from 2009 to 2015 and confirmed beneficial in developing and strengthening the coherence of frameworks to advance human resource development, justice and social rights, protection and social prosperity, and environmental sustainability. ${ }^{41}$ The implementation strategy of ASCC Blueprint 2025 related to the protection and preservation of the marine environment, then embedded into the 2016-2025 ASEAN Strategic Plan on the Environment (ASPEN). ${ }^{42}$ Seven priority points have been identified under the strategic plan, namely:

1) Nature conservation and biodiversity

2) Coastal and marine environment

3) Water resources management

4) Environmentally sustainable cities

5) Climate change

6) Chemicals and waste

\footnotetext{
${ }^{37}$ Nina von Toulon, "6 \& 7 SEPTEMBER EAST ASIAN SUMMIT CONFERENCE ON MARINE PLASTIC DEBRIS", Indonesia Waste Organization, 2017.

38 https://environment.asean.org/media-release-asean-conference-on-reducing-marine-debris-in-asean-region/, Accessed on March 4, 2020.

${ }^{39}$ Zhiyuan Ren, “THAILAND'S STRATEGIC CHOICE TO PARTICIPATE IN REGIONAL COOPERATION OF ASEAN COMMUNITY”, Advances in Social Science, Education and Humanities Research 416, (2020): 1560-1570, 1565, DOI: 10.2991/assehr.k.200316.331.

${ }^{40}$ ASEAN, ASEAN: A Community Oppurtunities (Jakarta: ASEAN Secretariat, 2015), 2.

${ }^{41}$ ASEAN, Asean Socio-Cultural Community Blueprint 2025 (Jakarta: ASEAN Sekretariat, 2015), 2.

${ }^{42}$ ASEAN, ASEAN Strategic Plan on Environment 2016-2025 Draft (Jakarta: ASEAN Sekretariat, 2017), 8.
} 
7) Environmental education (and sustainable consumption and production)

Strategic measurement of marine plastic litter issues implicitly included in second priority points of the ASEAN Strategic Plan. ${ }^{43}$ Furthermore, the implementation of a strategic plan on tackling marine plastic litter issue, administered through the establishment of an ASEAN institutional framework, namely the ASEAN Ministerial Meeting on Environment (AMME) and the ASEAN Senior Official on the Environment (ASOEN) supported by six working groups as an effort to implement ASCC Blueprint 2025, which will be described below: ${ }^{44}$

\section{b. ASEAN Ministerial Meeting on the Environment (AMME)}

The environmental management cooperation in the ASEAN region formulated for the first time in the ASEAN Environmental Program in $1977 . .^{45}$ in 1981 , the following the ASEAN Environment Program was held and organised by the ASEAN Ministerial Meeting on Environment (AMME) as one of the institutional body for ASEAN cooperation in environmental sectors. AMME administered by Ministers from ASEAN member states responsible for environmental management. AMME meetings held every two years. ${ }^{46}$ The effort taken by AMME regarding marine plastic litter in ASEAN regional sea has significantly developed since the Special ASEAN Ministerial Meeting on Marine Debris (SAMM-MD) on March 4-5, 2019 in Bangkok, Thailand was held. During the SAMM-MD, each ASEAN Member States delivered its country statement highlighting its actions to reduce marine debris includes pollution from plastic. For instance, the Philippines reported that the Manila Bay Rehabilitation Program would showcase its commitment to address marine debris. In general, the meeting aims to discuss possible steps and practical solutions related to marine debris, including plastic litter issues by the ASEAN Member States, also strengthen regional and international cooperation on waste management. ${ }^{47}$ The final results of the meeting are as follows:

\section{1) Bangkok Declaration on Marine Debris}

On June 22, 2019, ASEAN enacted the Bangkok Declaration on Combating Marine Debris, held at the 34th ASEAN Summit in Bangkok. ${ }^{48}$ In this Declaration, representatives of participating countries expressed their collective urge to overcome the global threat of pollution in the ASEAN regional marine environment, including plastic waste. The statement emphasised the commitment of member states to find solutions through cooperation and coordination between sectors and related parties, as well as the development of innovative solutions.ASEAN regional effort to deal with the marine plastic litter stipulated in the Bangkok Declaration, which emphasises several priority points, including: ${ }^{49}$

a) Strengthening actions at the national level and among ASEAN member countries and related parties to prevent and reduce marine waste, including plastics;

b) Promote intersectoral coordination;

c) Improve coordination and cooperation of various stakeholders;

d) Promote private sector involvement and investment;

\footnotetext{
${ }^{43}$ Lyons, Youna, Su, Theresa and Mei Lin Neo, A review of research on marine plastics in Southeast Asia: Who does what? (Singapore: National University of Singapore, 2019), 35.

${ }^{44} \mathrm{https}$ ://asean.org/asean-socio-cultural/asean-ministerial-meeting-on-environment-amme/, Accessed on March 4, 2020.

${ }^{45}$ G. Beatriz., Feng. M., Lin. J. Op. Cit., 16.

${ }^{46} \mathrm{http} / / /$ intl.denr.gov.ph/index.php/asean-environmental-groups/asean-high-level-meetings/article/4, Accessed on March 4, 2020.

${ }^{47}$ https://www.asean2019.go.th/en/infographic/why-should-we-care-about-marine-debris/, Accessed on March 4, 2020.

${ }^{48}$ Julios Cesar T. Op. Cit., 8.

${ }^{49}$ ASEAN, "Bangkok Declaration on Combating Marine Debris in ASEAN Region”, 2019.
} 
e) Strengthen research capacity and application of scientific knowledge

f) Accelerate advocacy and action to increase public awareness and participation and improve education about the protection of the marine environment.

2) ASEAN Framework of Action on Marine Debris

The Framework of Action on Marine Debris is the discussions result from representatives responsible in the field of natural, environmental and marine resources from all ASEAN Member Countries at the Special ASEAN Ministerial Meeting on Marine Debris on March 5 2019, in Bangkok, Thailand. ${ }^{50}$ This framework aims to strengthen collaborative action among ASEAN member countries and related parties to prevent and deal with marine plastic litter significantly. This framework consists of four priority areas explained by table below:

Table 1.2

ASEAN Framework of Action on Marine Debris

\begin{tabular}{|c|c|c|}
\hline No & Framework & Supporting Actions \\
\hline 1 & $\begin{array}{l}\text { Policy Support } \\
\text { and Planning }\end{array}$ & $\begin{array}{l}\text { 1. Promote regional policy dialogue on prevention and reduction } \\
\text { of marine debris from land- and sea-based activities by } \\
\text { highlighting the issue, sharing information and knowledge, } \\
\text { and strengthening regional coordination. } \\
\text { 2. The mainstream multi-sectoral policy is measures to address } \\
\text { marine debris in national and ASEAN's development agenda } \\
\text { and priorities. } \\
\text { 3. Encourage ASEAN Member States to implement relevant } \\
\text { international laws and agreements related to waste } \\
\text { management- such as MARPOL Annex V ship-generated } \\
\text { waste, Basel Convention, and UN Environment Assembly } \\
\text { resolutions } 3 / 7 \text { on Marine Litter and Microplastics. } \\
\text { 4. Develop a regional action plan on combating marine debris in } \\
\text { the ASEAN Region by applying integrated land-to sea policy } \\
\text { approaches. }\end{array}$ \\
\hline 2 & $\begin{array}{l}\text { Research, } \\
\text { Innovation and } \\
\text { Capacity } \\
\text { Building }\end{array}$ & $\begin{array}{l}\text { 1. Compile regional baseline on status and impacts of marine } \\
\text { debris in the ASEAN Region. } \\
\text { 2. Strengthen regional, national and local capacities to develop } \\
\text { and implement national action plans/initiatives. } \\
\text { 3. Enhance scientific knowledge, transfer marine technology and } \\
\text { promote an innovative solution to combat marine debris. } \\
\text { 4. Promote integration and application of scientific knowledge to } \\
\text { enhance science-based decisions and policies on marine debris } \\
\text { prevention and management. }\end{array}$ \\
\hline 3 & $\begin{array}{l}\text { Public } \\
\text { Awareness, } \\
\text { Education and } \\
\text { Outreach }\end{array}$ & $\begin{array}{l}\text { 1. Promote public awareness on the status and impacts of marine } \\
\text { debris and microplastics. } \\
\text { 2. Accelerate advocacy strategy/ programme to promote } \\
\text { behaviour change to combat marine debris, and to incorporate } \\
\text { marine debris issue into ASEAN's Culture of Prevention } \\
\text { Initiative. } \\
\text { 3. Promote platforms for knowledge sharing, innovative } \\
\text { solutions and best practices to combat marine debris }\end{array}$ \\
\hline
\end{tabular}

\footnotetext{
${ }^{50}$ https://asean.org/asean-framework-action-marine-debris/, Accessed on March 4, 2020.
} 


\begin{tabular}{|l|l|l|}
\hline 4 & $\begin{array}{l}\text { Private Sector } \\
\text { Engagement }\end{array}$ & $\begin{array}{l}\text { Promote collaborative actions with the private sector and } \\
\text { industry associations to implement measures to address } \\
\text { marine debris issues. }\end{array}$ \\
2. $\begin{array}{l}\text { Encourage private sector investment in and contribution to } \\
\text { combating marine debris. }\end{array}$
\end{tabular}

Sources: ASEAN Framework of Action on Marine Debris. Accessed on https://asean.org/asean-framework-action-marine-debris/

In general, these instruments focus on strengthening local laws and cooperation to combat marine debris, including plastic litters issue. It adopts a 'land-to sea approach'. It recognises the importance of multi-sectoral coordination, especially the engagement of the private sector and investment in preventing the problem of marine debris. ${ }^{51}$ These instruments are a milestone for the ASEAN Member states in dealing with pollution problems at sea. However, to ensure this initiative runs effectively, all parties must work together with their respective roles to take all possible steps to protect and preserve the marine environment.

\section{c. ASEAN Senior Official on the Environment (ASOEN)}

In 1989, the ASEAN Senior Official on the Environment (ASOEN) established to support AMME. ASOEN was previously known as the ASEAN Expert Group on the Environment (AEGE), which operates under the ASEAN Committee for Science and Technology. ${ }^{52}$ ASOEN has additional bodies or working groups that have specific mandates related to environmental preservation and protection. ASOEN and its working groups hold annual meetings to review the progress of the implementation of the ASCC Blueprint 2025 and the ASEAN Environmental Strategic Plan (ASPEN). The ASEAN Working Group on Coastal and Marine Environment (AWGCME) is a working group under ASOEN that is directly related to efforts to deal with marine pollution issue, including plastic litters. Concerning the Southeast Asia regional cooperation on marine plastic litter issues, AWGCME has been commissioned explicitly by ASOEN to act as the primary coordinating working group in the activity of handling marine waste problems in the ASEAN region with the support of other relevant working groups, such as the ASEAN Working Group on Chemicals and Waste (AWGCW) and the ASEAN Working Group on Sustainable Cities (AWGESC). Some concrete activities carried out by AWGCME in the effort of dealing with marine pollution, including plastic, are: ${ }^{53}$

1) The ASEAN Conference on Reducing Marine Debris in the ASEAN Region, organised by the Thai Ministry of Natural Resources and Environment in coordination with the ASEAN Secretariat in November 2017 in Phuket, Thailand.

2) ASEAN High-Level Dialogue on Oceans and Blue Economy 2018: Enhancing Regional Cooperation for Sustainable Fisheries and Marine Pollution in Southeast Asia.

3) Marine Waste Management Coordination Meeting in ASEAN, held in January 2019, in Phuket, Thailand.

4) ASEAN-Norway Cooperation Project on Local Capacity Building to Reduce Plastic Pollution in the ASEAN Region (ASEAN) held on December 9, 2019, in Jakarta, Indonesia.

5) Strengthening the Capacity for Reducing Marine Debris in the ASEAN Region through the Formulation of the National Action Plan for ASEAN Member Countries and the Integrated Land-to-Sea Policy Approach held in October 2019 in Bangkok, Thailand.

\footnotetext{
${ }^{51}$ Harsh Mahaseth, "dealing with marine debris the asean way- a critical analysis of asean framwork of action on marine debris and its impact", Vollkerechtsblog, (2020).

52 http://intl.denr.gov.ph/index.php/asean-menu/asean-groups/asean-high-level-meetings/article/3, Accessed on March 4, 2020.

${ }^{53}$ Ibid.
} 
6) ASEAN-EU Project on Circular Economy which was held on 11-12 June 2019 in Kuala Lumpur, Malaysia to present EU policies and legislation related to plastics, plastic waste and promotion of the use and regulation of plastic waste.

Cooperation between Southeast Asian countries under the ASEAN institutional framework has successfully adopted several instruments as evidence of the commitment of member countries in protecting their marine environment. ${ }^{54}$ The series of efforts that have been carried out by ASEAN in dealing with marine pollution issue is proof that ASEAN is aware of the urgency and importance of their role as the primary organisation in Southeast Asia. However, the instrument still possesses several shortcomings and challenges. Based on the data above, it showed that neither the Framework nor the Declaration ban explicitly single-use plastics or imports of foreign waste, which plastic is the most significant pollutant at sea, worsen by a trend of plastic waste imports amongst Southeast Asian countries. According to data from the International Trade Center, ASEAN's plastic waste imports surged last year to more than 2.2 million tonnes or 27 per cent of the total import worldwide. It was up from 11 per cent of the worldwide total in 2017, and just over 5 per cent in 2016. ${ }^{55}$

Moreover, another challenge originates from a strict ASEAN principle of non-interference that leaves the necessary decision-making process in the hands of member countries. This approach was helpful in the formative years (the 1960s-70s), allowing states to deal with their domestic problems without intervention from other members states. However, the organisation needs a change to a rules-based regime and more reliable regional integration to be effective. This principle will potentially be causing lacks of enforcement mechanisms and provoked states to rely on negotiation and consultation to resolve disputes, without taking recourse to any legal consequences for non-compliance or breach of the Agreement. Therefore, it is indeed a concern that the instrument adopted by ASEAN will be implemented ineffectively. ${ }^{56}$ However, this concern is not impossible to overcome. The author gives several suggestions for applicable initiatives and strategic steps based on the data that has been described, such as :

1) Strengthening national policies for each member states;

2) Establishing intersectoral cooperation;

3) Increasing public awareness;

4) Maintaining collaboratives partnership with existing potential partners; such as international organisations, non-governmental organisations, local government, civil society, media, academia and scientists;

5) Enhancing the effectiveness of strategies with various stakeholders and the public to generate support, garner awareness, and promote the active participation of the whole community regarding the protection and preservation of the environment from the plastic waste pollution.

\section{Conclusion}

Southeast Asia regional cooperation on marine plastic litter is pioneered by the regional organisation of the Association of South-East Asia Nations (ASEAN) based on the ASEAN Socio-Cultural Community (ASCC) Blueprint 2025. The implementation of the ASEAN Blueprint 2025 related to the protection and preservation of the marine environment is carried out through the ASEAN institutional framework, namely the ASEAN Ministerial Meeting on Environment (AMME) and ASEAN Seniors Official Meeting on the Environment (ASOEN). The two institutional frameworks have produced two instruments, namely the Bangkok

\footnotetext{
${ }^{54}$ Nguyen Thi Xuan Son, "POLICY ON MARINE PLASTIC WASTE IN ASEAN AND VIETNAM", Environmental Claims Journal, (2020): 1-13, 2, DOI: 10.1080/10406026.2020.1775347

${ }^{55}$ Neo Chai Cin, "ENCOURAGING START, BUT ASEAN HAS TO GO BEYOND ITS PLEDGE TO TACKLE MARINE WASTE”, Eco-Business, June 2019.

56 ASEAN, "ASEAN Strategic Plan on Environment 2016-2025 Draft”, Op.Cit., 14.
} 
Declaration on Marine Debris and the ASEAN Framework of Action on Marine Debris and several related programs organised by the ASEAN Working Group on Coastal and Marine Environments (AWGCME). Unfortunately, ASEAN does not yet have a Regional Action Plan explicitly addressing the problem of plastic waste at sea, so that the series of programs that have been implemented are expected to be a reference in the formation of Regional Action Plans in the future.

\section{A. Journal and Article}

\section{References}

Ahmad K, Khairunnisa. "AN ASSESSMENT OF MARINE PROTECTED AREAS AS A MARINE MANAGEMENT STRATEGY IN SOUTHEAST ASIA: A LITERATURE REVIEW", Ocean and Management 145, no. 1, 2017: 72-81, DOI: 10.1016/j.ocecoaman.2017.05.008

Ansje, L., et. al. "SOLUTION FOR GLOBAL MARINE LITTER POLLUTION". Current Opinion in Environmental Sustainability, no. 28, 2017: 90-100, DOI: 10.1016/j.cosust.2017.08.009.

Beatriz, G., et. al. "MARINE PLASTIC POLLUTION IN ASIA:ALL HANDS ON DECK!". Chinese Journal of Environmental Law 3, no. 1, 2019: 11-46, DOI:10.1163/2468604212340034.

Cesar T, Julius. "MARINE ENVIRONMENTAL PROTECTION AND COOPERATION: AN ASEAN-CHINA FRAMEWORK?". RSIS Commentary no.113, 2017: 1-4.

Dauvergne, Peter "WHY IS THE GLOBAL GOVERNANCE OF PLASTIC FAILING THE OCEANS?", Global Environmental Changes 51, 2018: 22-31. DOI: 10.1016/j.gloenvcha.2018.05.002

Duhec, Aurélie V. "COMPOSITION AND POTENTIAL ORIGIN OF MARINE DEBRIS STRANDED IN THE WESTERN INDIAN OCEAN ON REMOTE ALPHONSE ISLAND, SEYCHELLES", Marine Pollution Bulletin 96, no. 1-2, 2015: 76-86, DOI: 10.1016/j.marpolbul.2015.05.042

Forest, Craig. "STATE COOPERATION IN COMBATING TRANSBOUNDARY MARINE POLLUTION IN SOUTH EAST ASIA", Australian and New Zealand Maritime Law 30, no. 1, 2016: 78-89.

Gargani, Luisa., et. al. "IMPACT OF MARINE LITTER". Frontiers in Marine Science 6, 2019: 1-8, DOI: $10.3389 /$ fmars.2019.0020.

Giulia, C., Konstantin, K. "ADVANCING THE INTERNATIONAL REGULATION OF PLASTIC POLLUTION BEYOND THE UNITED NATIONS ENVIRONMENT ASSEMBLY RESOLUTIONS ON MARINE LITTER AND MICROPLASTICS”. Review of European, Comparative and International Environmental Law 27, no. 3, 2018: 234-244, DOI: $10.1111 /$ reel/12258.

Harsh Mahaseth. "DEALING WITH MARINE DEBRIS THE ASEAN WAY - A CRITICAL ANALYSIS OF ASEAN FRAMEWORK OF ACTION ON MARINE DEBRIS AND ITS IMPACT". Vollkerechtsblog, 2020.

Haward, M. "PLASTIC POLLUTION OF THE WORLD'S SEAS AND OCEAN AS CONTEMPORARY CHALLENGE IN GOVERNANCE". Nature Communications 9, no. 1, 2018: 1-3, DOI: 10.1038/s41467-018-03104-3.

Jambeck, J. R., Geyer, R., \& Wiloex, C. "PLASTIC WASTE INPUTS FROM LAND TO OCEAN”. Sciencemag 347, no. 6223, 2015: 768-771, DOI: 10.1126/science.1260879.

Joane P. T, Ma. Gregoria. "MANAGEMENT FRAMEWORKS FOR COASTAL AND MARINE POLLUTION IN THE EUROPEAN AND SOUTHEAST ASIA REGION", Ocean and Management 135, 2017: 65-78, DOI: 10.1016/j.ocecoaman.2016.11.003 09645691/. 
Kikman, Hugh. "THE EAST ASIAN SEAS UNEP REGIONAL SEAS PROGRAMME". International Environment Agreements Springer 6, no. 3, 2006: 305-316, DOI: 10.1007/S|074-006-9011-5.

Lasut, Markus T. "FROM CORAL TRIANGLE TO TRASH TRIANGLE- HOW PLASTIC WASTE THREATENS THE HOT SPOT OF GLOBAL MARINE BIODIVERSITY". Proceedings of the International Conference on Microplastic Pollution in the Mediterranean Sea, Springer Water, 2018, DOI: 10.1007/978-3-319-71279-6_1.

LC, Lebreton., et. al. "RIVER PLASTIC EMISSIONS TO THE WORLD'S OCEANS". Nat. Commun 8, no.15611, 2017: 1-8, DOI: 10.1038/ncomms15611.

Neo Chai Cin. "ENCOURAGING START, BUT ASEAN HAS TO GO BEYOND ITS PLEDGE TO TACKLE MARINE WASTE". Eco-Business, 2019.

Nopriandi, Tedy., Ardhiansyah, Risky Fany. "PARADIGM OF DEATH PENALTY (COMPARATIVE STUDY IN INDONESIA, SAUDI ARABIA AND CHINA)", Lampung Journal of International Law (LaJIL) 2, no. 1, 2020: 47-56.

Piyaporn Wongruang. "SPECIAL REPORT: ALARM RAISED AS THAILAND DROWNS IN PLASTIC TRASH". The nation Thailand,05 May 2018.

Ren, Zhiyuan. “THAILAND'S STRATEGIC CHOICE TO PARTICIPATE IN REGIONAL COOPERATION OF ASEAN COMMUNITY". Proceedings Article published 2020 in Proceedings of the 4th International Conference on Culture, Education and Economic Development of Modern Society (ICCESE 2020), DOI: https://doi.org/10.2991/assehr.k.200316.331.

Sarva, M. P., Siti N. M., Shinichi A, "EXPLORATION OF MICROPLASTICS FROM PERSONAL CARE AND COSMETIC PRODUCTS AND ITS ESTIMATED EMISSIONS TO THE MARINE ENVIRONMENT: AN EVIDENCE FROM MALAYSIA", Marine Pollution Bulletin 136, 2018: 135-140, DOI: 10.1016/j.marpolbul.2018.09.012.

Son, Nguyen Thi Xuan. "POLICY ON MARINE PLASTIC WASTE IN ASEAN AND VIETNAM", Environmental Claims Journal, 2020: 1-13. DOI: 10.1080/10406026.2020.1775347

Sumaila, U. Rashid. "COMPARATIVE VALUATION OF fiSHERIES IN ASIAN LARGE MARINE ECOSYSTEMS WITH EMPHASIS ON THE EAST CHINA SEA AND THE SOUTH CHINA SEA LMES”, Deep-Sea Research Part II 163, 2019: 96-101, DOI: 10.1016/j.dsr2.2018.12.008.

Tahar, Abdul Muthalib., Prasetyawati, S Endang. "KAJIAN HARMONISASI HUKUM PERSAINGAN TIGA NEGARA ANGGOTA ASEAN BERDASARKAN THE ASEAN REGIONAL GUIDELINES ON COMPETITION POLICY STUDY OF HARMONIZATION OF COMPETITION LAWS OF THREE ASEAN MEMBER COUNTRIES BASED ON THE ASEAN REGIONAL GUIDELINES ON COMPETITION POLICY," Cepalo 2, no. 1, 2019: 1-20, 2, DOI: 10.25041/cepalo.v2no1.1758.

Toulon, Nina von. "6 \& 7 SEPTEMBER EAST ASIAN SUMMIT CONFERENCE ON MARINE PLASTIC DEBRIS”. Indonesia Waste Organization, 2017.

Truong, Nguyen van., BeiPing, Chu. "PLASTIC MARINE DEBRIS: SOURCES, IMPACTS AND MANAGEMENT”, International Journal of Environmental Studies, 2019: 10-20, DOI: $10.1080 / 00207233.2019 .1662211$

Vince, Joanna., Denise H, Britta. "PLASTIC POLLUTION CHALLENGES IN MARINE AND COASTAL ENVIRONMENTS: FROM LOCAL TO GLOBAL GOVERNANCE", The Journal of the Society for Ecological Restoration 25, no. 1, 2016: 123-128, DOI: 10.1111/rec. 12388 
Werner, Stefanie. "MARINE PLASTIC LITTER- A MASSIVE WASTE PROBLEM". Journal for Waste Resources and Residues 1, no. 1, 2018: 128-133, DOI: 10.26403/detritus/2018.21.

Xhantos, D. Walker, T.R. "INTERNATIONAL POLICIES TO REDUCE PLASTIC MARINE POLLUTION FROM SINGLE-USE PLASTIC”. Elsevier Journal 118, no. 1-2, 2019: 17 26. DOI: 10.1016/j.marpolbul.2017.02.048.

\section{B. Book}

ASEAN. ASEAN Socio-Cultural Community Blueprint 2025, Jakarta: ASEAN Sekretariat, 2015.

ASEAN. ASEAN Strategic Plan on Environment 2016-2025 Draft, Jakarta: ASEAN Sekretariat, 2017.

ASEAN. ASEAN: A Community Opportunities. Jakarta: ASEAN Secretariat, 2015.

ASEAN. Bangkok Declaration on Combating Marine Debris in ASEAN Region, Jakarta: ASEAN Sekretariat, 2019.

Kershaw, Peter J. Marine Plastic Debris \& Microplastic. Nairobi: UNEP, 2016.

Koh. K. L., Nicholas. A.R., Lye. L. ASEAN Environmental Legal Integration. Cambridge: Cambridge University Press, 2016.

Lyons, Youna., Su, Theresa., Mei Lin Neo. A review of research on marine plastics in Southeast Asia: Who does what?. Singapore: National University of Singapore, 2019.

Porter Hoagland, D. Jin. 2006. UNEP Regional Seas Report and Studies No. 181. Netherland: UNEP.

Special Survival Commission. IUCN Red Categories and Criteria. Swiss: IUCN, 2012.

C. Internet

http://intl.denr.gov.ph/index.php/asean-environmental-groups/asean-high-levelmeetings/article/4, Accessed on March 4, 2020.

http://intl.denr.gov.ph/index.php/asean-menu/asean-groups/asean-high-levelmeetings/article/3, Accessed on March 4, 2020.

https://asean.org/asean-framework-action-marine-debris/, Accessed on March 4, 2020.

https://asean.org/asean-socio-cultural/asean-ministerial-meeting-on-environment-amme/, Accessed on March 4, 2020.

https://asean.org/storage/2019/03/3.-Joint-Media-Statement-SAMM-5-March-2019-Thai-

Logo.pdf, Accessed on March 4, 2020.

https://environment.asean.org/media-release-asean-conference-on-reducing-marine-debris-inasean-region/, Accessed on March 4, 2020.

https://www.asean2019.go.th/en/infographic/why-should-we-care-about-marine-debris/

Accessed on March 4, 2020.

https://www.unenvironment.org/cobsea/who-we-are, Accessed on March 4, 2020. 
$\underline{ }$ 